\title{
Portuguese Airport Efficiency Analysis: The Case Study of Oporto
}

\author{
Maria José Palma Lampreia dos Santos \\ Mafalda Mendes-Ribeiro \\ Isabel Andrés Marques \\ José Manuel Pereira \\ Corresponding author: Maria José Palma Lampreia dos Santos, DINÂMIA 'CET-ISCTE - School of Communication and \\ Media Studies, Polytechnic Institute of Lisbon, Portugal; E-mail: mjpls1963@gmail.com \\ Lusofona University of Porto, Portugal; E-mail: mafaldamribeiro@sapo.pt \\ Lusofona University of Porto, Portugal; E-mail: isabelandres@gmail.com \\ IPCA - Polytechnic Institute of Cávado and Ave, Portugal; Email: jpereira@ipca.pt
}

\section{Doi:10.5901/mjss.2015.v6n6s2p390}

\section{Abstract}

The Oporto Airport located in the northern region in Porto city is crucial because is the only one located in the northern region. This airport had an increasing in number of passengers, sales revenue and accumulated investment during the last two decades, principally after the introduction and the operation of the Low Cost Companies since 2004 to the present. In order to determine if the last changes had an impact in the competitiveness of this airport, the main aims is to analise the evolution of values of the technical efficiency and equate the results before and after the introduction of the LCCs in this airport. The methodology uses the Data Envelopment Analysis. Results show that the Oporto Airport efficiency increases highly after the introduction of LCCS since 2004. The main conclusions suggest the importance of the introduction of LCCs in the increasing efficiency of the Oporto Airport and the potential relation with tourism development in this region, but more strong studies are needed.

Keywords: Data Envelopment Analysis; technical efficiency; Oporto Airport; Low Cost Companies; tourism development

\section{Introduction}

In Portugal mainland there are three civil airports located one on the Northern (Oporto) and two in the South, namely, in Lisbon and Faro. The Oporto Airport (OPA) is crucial by its coverage and your influence goes up from the North of the country until quite the South. Despite the gap on information's sources from INE (2012) and INAG (2013) and ANA (2012) the OPA contribute about almost half of the passengers' traffic in Portugal mainland. In the tourism sector this airport is also crucial because is the main entrance of tourists on the North of the country. Since 2004 this airport started the operation of the Low Cost Companies (LCCs) together with the traditional full services airlines companies. The OPA volume of passenger's, accumulated investment and sales revenues, however, had an evolution on the opposite direction, towards the growth during the last decade, principally, after the introduction of LCCs, since 2004. Therefore, during this period (2004-2010) the number of passengers increasing about $80 \%$, the accumulated investment infrastructure increasing $64 \%$ and sales revenue led to a huge increasing of $105 \%$.

According to this results and the crucial importance of this airport in the national civil aviation industry, the intent of this work is to study the competitiveness of the introduction of the LCCs companies in the OPA. The main goal of this study is to determine if the LCCs companies led effectively to an increasing in the efficiency of the OPA. In order to achieve this goal the main aim of this work is to measure the levels of technical efficiency during a time horizon 19902011 in OPA by the airlines based on OPA, and compare the results before and after the introduction of the low cost companies (LCCS) in OPA, and relate these efficiency levels to some potential consequences in tourism in Porto and North of the Portugal. This paper contributes for airport managers and decision makers better generate insights to better adjusting measures to airport management and sectorial politics like tourism. 


\section{Literature Review}

According to Rey (2010), there is a huge influence of LCCs on tourism demand, and this expansion has positive direct and indirect effects on the economy. The development of tourism is closely linked to the evolution of transport and it is undeniable that nowadays the airline industry is central to the tourism industry (Cunha, 2009). The continuous development of tourist destinations and the growth of the existing ones require continuous and responsible destination management (Assaf and Josiassen (2012); Armenski, et al, 2012).

It is recognized that "the addition of a single international flight can have a discernible impact on receipts and employment in the tourism sector, with positive spill over effects throughout the broader economy" (Bowen, 2000, p. 27). Several tourism studies have so far analysed different aspects of the airline industry. From a tourist's point of view, the two most important decisions that relate to tourism decision are the choice of destination and the choice of airline. The two most expensive elements in an average tourist's budget are accommodation and the airfare (Assaf and Josiassen (2012).

Tourism includes a wide range of economic activities that have an important impact on the environment destinations (Assaf and Josiassen, 2012; Malgorzata and Dominique, 2013). In the last decades tourism became one of the major industries in the world economy (Surugiu et al., 2011) and the airline industry has a very important role in this sector. In other words, more efficient airlines are able to lower the price and attract more travellers to a particular destination (Assaf and Josiassen, 2012; Morley, 2003).

The international airline industry has experienced a turbulent period in the last decade and has faced significant financial challenges in 2008 and 2009. Over the past decade the global tourism industry has encountered many shocks making the tourism industry extremely venerable, (Assaf and Josiassen, 2012; Aimable and Rosselló, 2009). The industry revenues loss in 2009 fell 15\%, or $\$ 85$ billion, since the tragic events of September 2001 (IATA, 2010).

There is a comprehensive body of literature focusing on issues of airline efficiency and productivity (Assaf and Josiassen, 2012; Barbot et al., 2008). According to Barros et al., (2013) and Barros \& Peypoch, (2009) contemporary research in airline frontier models encompasses, several scientific methods to analyse efficiency quantitatively, namely the old tradition of the cost models, the total factor productivity approach, the contemporary stochastic econometric frontier models and the DEA models. The models, inputs and outputs used in the various papers published in airport efficiency according to Barros and Managi, (2008) and actualized by the present authors are present in Annex $1 \mathrm{~A}$.

\section{Research Methodology}

Data Envelopment Analysis (DEA) is a non-parametric measure of efficiency analysis, so have some advantages to other econometric methods to measure the efficiency. So the main advantage it is not necessary to define a production fuction. (Jurcevic, B. and Zaja, M., 2013 Dos-Santos, 2013, Hengzhou, X., Tong, C. 2013, Silva et al., 2012a, Silva et al., 2012b and Silva et al., 2012c) .

The use of DEA efficiency measures are not very affected when we have a smaller number of observations as occur in the present case. (Thiam et al 2001; Chambers, 1998). Some authors refer to some disadvantages with the use of DEA methodology, however, results from previous authors confirm they did not obtain significant differences in the results s whith parametric and non-parametric methods. (Alene and Zeller, 2005; Thiam et al., 2001; Wadud and White, 2000; Martin and Román, 2001).

By the use of DEA methodology theproduction unit (PU) using fewer inputs to produce the same amount of output PU is more efficient. Thus the efficient units end up doing the production frontier without this be defined in advance. (Speelman et al., 2007. On the present paper we use an input-orientated model because we assumed that airport managers have more control over input quantities than over outputs. On the present work we solve DEA applying by the Program (DEAP) that was fIRSCALtly developed by Coelli (1996).

The present paper uses Banker et al., (1984) technique which includes convexity restrictions on the mathematical programming model, which allows to calculate the variables with returns to scale. Thus it is possible to divide the overall technical efficiency (TE) in pure technical efficiency (PTE) and scale efficiency (SE). The IRSCALt is similar to (PTE). The scale efficiency occurs when the economy of scale is constant and equal to 1 (Barros and Peypoch, 2009). According this and Barbot et al., (2008) the model is:

$$
\begin{aligned}
& \min _{\theta, s_{i}^{-}, s_{r}^{+}}\left(\theta-\varepsilon\left(\sum_{i=1}^{m} s_{i}^{-}+\sum_{r=1}^{s} s_{r}^{+}\right)\right) \\
& \sum_{j=1}^{n} x_{i j} \lambda_{j}+s_{i}^{-}=\theta x_{i 0}, \quad i=1, \ldots, m \\
& \sum_{j=1}^{n} \gamma_{r j} \lambda_{j}-s_{r}^{+}=\gamma_{r 0}, \quad r=1, \ldots, s
\end{aligned}
$$




$$
\begin{aligned}
& \sum_{j=1}^{n} \lambda_{j}=1, \quad j=1, \ldots, n \\
& \lambda_{0}=0 \\
& \lambda_{j} \geq 0, s_{r}^{+} \geq 0, \quad s_{i}^{-} \geq 0, \forall i, j, r
\end{aligned}
$$

where $x_{i j}$ is the ith input of DMU $j$; where $y_{i j}$ is the rth input of DMU $j ; \theta$ is the efficiency score of the considered $\mathrm{DMU} ; \sum_{j=1}^{n} \lambda_{j}=1$ is the convexity constraint in the Banker-Charnes-Cooper model: $s_{i}^{-}$is an input slack parameter; $s_{r}^{+}$is an output slack parameter; $\lambda_{0}=0$ is a constraint for applying the super-efficiency measure (Barbot et al., 2008).

In order to select the inputs and output variables we analysed other works in this field according to Barros (2008a) and actualized the information (Annex 1A).

The paper use a time series from 1990 to 2011 comprising twenty-one years from OPA obtained from different sources, namely, INE, INAC and ANA which comprise for all of them annual reports of Portuguese airports data and information. The model used in this study includes two output variables and two inputs. Inputs are total operational cost, and investment. Outputs are sales revenue and total passengers in number. Monetary magnitudes are expressed in euros (000 euros), deflated by the GDP deflator and denoted at prices of 2000. This inputs and output selection is according previous authors refereed principally by Barros et al. (2008), but adapted. The summary statistics of the variables of interest are presented in Table 1.

Table 1: Inputs and outputs used

\begin{tabular}{|l|c|c|c|c|}
\hline Inputs/outputs & Average & Standard Deviation & Minimum & Maximum \\
\hline Total operation cost (000 euros) & 16902,24 & 6955,753 & 5894 & 31010 \\
Investment (000 euros) & 23840 & 34018,78 & 1098 & 122368 \\
Sales revenue (000 euros) & 31150,57 & 16190,6 & 9078 & 67823 \\
Total passengers (000 number) & 2798492 & 1062167 & 1355683 & 5283361 \\
\hline
\end{tabular}

Source: INAC/INE/ANA (reports from 1990 to 2011) and author's calculations, 2013

\section{Findings and Discussion}

The main results of the DEA values, namely, TE, PTE and SCAL are presented in Table 2. The percentage of efficient years of the OPA represents the share of years with an efficiency score of the unity. The results confirm that the OPA only was efficient in 6 years that represente $29 \%$ of the total number of years in study. The mean value of technical efficiency was 0,87 . It is possible to obtain the same value of the output saving approximately $13 \%$ of the vaue of the inputs. The results of the efficiency before the introduction of LCCs in OPA (1990-2004) showed that the OPA during a period of 14 years only was efficient in 2 years thus representing a $14 \%$ of the total time horizon in study. The average of technical efficiency was 0,87 . The results of the efficiency after the introduction of LCCs in OPA (2005-2011) showed that the OPA during a period of 6 years was efficient in 5 years thus representing more than $83 \%$ from the total of the time horizon in study. The average of technical efficiency was 0,98 .

These results showed a big difference in OPA before and after the introduction of the LCCs. After the introduction of the LCCs the OPA becomes quite efficient. The efficiency is nearly 100\% (98\%). The LCCs favoured highly the OPA and the tourism in Porto and North of Portugal according to Marques (2013). According to INE (2013) from 2004 to 2011 the number of guests in hospitality establishments has been showing a huge increase since the introduction of the LCCs in OPA. This increasing is about 44\% from 2004 to 2011. These results highlights the importance of having airports and airline companies operating efficiently to the development of the tourism sector, although further studies are needed in order to give more robustness to these findings.

The TE is divided into two components, PTE and SE. TE is 0,97 and PTE is 0,87 during all the time horizon analysed and scale inefficiency is $13 \%$. It occurs due the fact that $94 \%$ of the years the airport operation works in in increasing returns to scale (IRSCAL) and $20 \%$ be operating in decreasing returns to scale (DRSCAL). Between a period 1990-2004 technical TE from IRSCAL is 0,97 and SE is 0,82. Scale inefficiency (18\%) may occur due to an operation below the optimal scale, as a result of the fact that a $100 \%$ of years operate at increased returns to scale (IRSCAL).

After the introduction of the LCCs in OPA from 2005 to 2011 TE from PTE is 0,97 and SE is 0,98. SE is near zero during this period. 
Table 2. Model results

\begin{tabular}{|c|c|c|c|}
\hline & $\mathrm{TE}$ & PTE & SCAL \\
\hline Mean & 0,87 & 0,97 & 0,87 \\
\hline Standard deviation & 0,14 & 0,05 & 0,14 \\
\hline Maximum & 1 & 1 & 1 \\
\hline Minimum & 0,54 & 0,81 & 0,54 \\
\hline Efficient years & 6 & 15 & 4 \\
\hline IRSCAL & & & $94 \%$ \\
\hline DRSCAL & & & $6 \%$ \\
\hline \multicolumn{4}{|c|}{ DEA results of OPA before LCCs (1991-2004) } \\
\hline & $\mathrm{TE}$ & PTE & SE \\
\hline & 0,82 & 0,97 & 0,82 \\
\hline & 0,15 & 0,06 & 0,15 \\
\hline $\begin{array}{l}\text { Standard deviation } \\
\text { Maximum }\end{array}$ & 1 & 1 & 1 \\
\hline $\begin{array}{l}\text { Minimum } \\
\text { Efficient years }\end{array}$ & 0,54 & 0,81 & 0,54 \\
\hline Efficient years & 2 & 9 & 1 \\
\hline \multirow{2}{*}{\begin{tabular}{|l} 
IRSCAL (\%) \\
DRSCAL (\%)
\end{tabular}} & 12 & 0 & 100 \\
\hline & & & 0 \\
\hline \multicolumn{4}{|c|}{ DEA results of OPA after the introduction LCCs (2005-2011) } \\
\hline \multicolumn{2}{|r|}{ TE } & PTE & SE \\
\hline \multirow{7}{*}{$\begin{array}{l}\text { Mean } \\
\text { Standard deviation } \\
\text { Maximum } \\
\text { Minimum } \\
\text { Efficient years (number) } \\
\text { IRSCAL } \\
\text { DRSCAL } \\
\end{array}$} & 0,98 & 0,99 & 0,98 \\
\hline & 0,02 & 0,02 & 0,01 \\
\hline & 1 & 1 & 1 \\
\hline & 0,94 & 0,96 & 0,96 \\
\hline & 5 & 3 & 3 \\
\hline & & & 50 \\
\hline & & & 50 \\
\hline
\end{tabular}

Source: Authors calculations, 2013.

\section{Concluding Remarks}

The paper provides an estimation of the non-parametric technical efficiency during a time horizon 1990-2011; since 1990 to 2004 (before the introduction of LCCs in OPA) and after the operations of LCCs in OPA, from 2005 to 2011. The main conclusion suggest that the LCCs highly contribute to the increasing of the efficiency in this airport. Therefore it is necessary more detailed studies in order to analyse the direct and indirect impact in tourism activity in Porto and North of Portugal. It is also necessary more detailed data and information in order to improve the adopted innovative methodologies, namely the second-stage regression efficiency, in order to know what the variables that influence the airport efficiency are. This paper tries to give relevant information for decisions makers in order to better adjust their decisions and improve and maintain the efficiency of OPA. This is an important tool that strengths the importance of local tourism, but more studies in complementary areas of economics of tourism are needed.

According to this results, the increase of the efficiency on the OPA is directly related to the arrival of the LCCS, and is knowing that the LCCs effects on air transport demand is very important, particularly for some segments of travellers such as tourists, we can say that is very important that all stakeholders of the tourism sector will continue to encourage the growth of LCCS at OPA, in order to consolidate the predominant role that these airline companies have on the demand and development of tourism in the region of Porto and Northern of Portugal.

\section{References}

Adler, N., Berechman, J. (2001). Measuring Airport Quality from the Airlines Viewpoint: An Application of Data Envelopment Analysis. Transport Policy, 8:171-181.

Aimable, E., Rosselló, J. (2009). The Short-Term Impact of 9/11 on European Airlines Demand. European Journal of Tourism Research, 2 (2) 145-161.

Alene, A., Zeller, M., (2005). A comparison of production and distance function approaches to technical efficiency measurement: With applications to adopters of improved cereal technology in Eastern Ethiopia. Agricultural Economics Review, 6 (1), 5-17.

ANA - Aeroportos de Portugal (2012). Relatórios Anuais de Tráfico referentes a vários anos. 
Armenski, T., Gomezelj, D., Djurdjev, B., Curcic, N. and Dragin, A. (2012). Tourism Destination Competitiveness- Between Two Flags. Economic Research, 25 (2), 485-502.

Assaf, A. G., Josiassen, A., (2012). European vs. U.S. airlines: Performance comparison in a dynamic market. Tourism Management, $33: 2,317-326$.

Banker, R., Charnes, A. and Cooper, W.W. (1984). Some models for estimating technical and Scale inefficiencies in data envelopment analysis. Management Science, 30, 1078-1092.

Barbot, C., Costa, A. and Sochirca, E. (2008). Airlines performance in the new market context: A comparative productivity and efficiency analysis. Journal of Air Transport Management, 14, 270- 274.

Barros, C.P. (2008a). Technical change and productivity growth in airports: A case study". Transportation Research, Part A, 42- 5, 818832.

Barros, C.P. (2008b). The Technical Efficiency of UK Airports. Mimeo.

Barros, C.P., Couto, E. (2013). Productivity analysis of European airlines 2000 - 2011. Journal of Air Transport Management, 31, 11-13.

Barros, C.P., Dieke, P.U.C. (2007). Performance Evaluation of Italian Airports with Data Envelopment Analysis. Journal of Air Transport Management, 13, 184-191.

Barros, C.P., Dieke, P.U.C. (2008). Measuring the Economic Efficiency of Airports: A Simar-Wilson Methodology Analysis. Transportation Research Part E (forthcoming).

Barros, C.P., Liangc, Q.B. and Peypochc, N. (2013). The technical efficiency of US. Airlines. Transportation Research Part A: Policy and Practice, 50, 139-148.

Barros, C.P., Managi, S. (2008). Productivity Change of UK Airports: 2000-200.WP 22/2008/DE/UECE. Working Papers.

Barros, C. P., \& Peypoch, N. (2009). An evaluation of European airlines' operational performance. International Journal of Production Economics, 122(2), 525-533.

Barros, C.P., Sampaio, A. (2004). Technical and Allocative Efficiency in Airports. International Journal of Transport Economics, 31, 355377.

Boussafian, A., Dysson, R.G. and Thanassoulis, E. (1991). Applied data envelopment analysis. European Journal of Operational Research, 52, 1-15.

Bowen, J. (2000). Airline hubs in Southeast Asia: national economic development and nodal accessibility. Journal of Transport Geography, 8, 25- 41.

Chambers, R.G., Fare, R., Jaenicke, E. and Lichtenberg, E. (1998). Using dominance in forming bounds on DEA models: the case of experimental agricultural data. Journal of Econometrics, 85, 189-203.

Charnes, A., Cooper, W. and Rhodes, E. (1978). Measuring the Efficiency of Decision Making Units. European Journal of Operational Research, 2, 429-444.

Charnes, A., Cooper, W. and Rhodes, E. (1981). Evaluating Program and Managerial Efficiency: An Application of Data Envelopment Analysis to Program Follow Through. Management Science, 27(6): 668-697.

Coelli, T. (1996). A Guide to DEAP Version 2.1: A data envelopment analysis (computer) program. CEPA Working Papers nº/96, University of New England, Australia.

Coelli, T., Rao, P. and Battese, G. (1998). An Introduction to Efficiency and Productivity Analysis. Norwell: Kluwer Academic Publishers.

Cunha, L. (2009). Introdução ao Turismo, Editorial Verbo, Lisboa-São Paulo, $4^{\circ}$ edição.

Dos-Santos, M.J.P. L. (2013). Segmenting Farms in European Union. Agricultural Economics Czech, 59, 49-57.

Fernandes, E., Pacheco, R.R. (2007) Airport management: a strategic approach. Transportation, 34 (1), 129-142.

Gillen, D., Lall, A. (2001). Developing Measures of Airport Productivity and Performance: An Application of Data Envelopment Analysis. Transportation Research, Part E, 33, 261-273.

Hengzhou, X., Tong, C. (2013) Impact of farmers' differentiation on farmland-use efficiency: Evidence from household survey data in rural China. Agricultural Economics - Czech, 59, 227-234

IATA - International Air Transport Association, (2012)."Annual Report 2010 and various years. Unpublished data.

INAC - Instituto Nacional da Aviação Civil (2013). Relatório Económico do Transporte Aéreo" Português. Unpublished data.

INE - Instituto Nacional de Estatística (2012). Estatísticas do Transporte Aéreo, Lisboa. Unpublished data.

Jurcevic, B., Zaja, M. M. (2013). Banks and Insurance Companies Efficiency indicators in the Period of Financial Crisis: The Case of the Republic of Croatia. Economic Research, 26 (1), 203-224.

Malgorzata, O., Dominique T. (2013). Sustainable tourism and the emergence of new environmental norms. European Journal of Tourism Research, 6 (2), 141-153.

Martin C.J., Román C. (2001). An Application of DEA to Measure The Efficiency of Spanish Airports Prior to Privatization. Journal of Air Transport Management, 7(3), 149-157.

Morley, C.L. (2003) Impacts of international airline alliances on tourism. Tourism Economics London, 9, 31-51.

Murillo-Melchor, C. (1999). An Analysis of Technical Efficiency and Productive Change in Spanish Airports Using the Malmquist Index. International Journal of Transport Economics, 26, 271-92.

Parker, D. (1999). The Performance of the BAA Before and After Privatisation. Journal of Transport Economics and Policy, 33, 133-146.

Pels, E., Nijkamp, P. and Rietveld, P. (2001). Relative Efficiency of European Airports. Transport Policy, 8, 183-192.

Pels, E., Nijkamp, P. and Rietveld, P. (2003). Inefficiency and Scale Economics of European Airport Operations. Transportation Research Part E, 39, 341-361.

Rey B., Myro, R. and Galera, A. (2010). Effect of low-cost airlines on tourism in Spain. A dynamic panel data model. Journal of Air 
Transport Management, XXX, 1-5

Sarkis, J. (2000). Operational Efficiency of Major US Airports. Journal of Operation Management, 18, 335-251.

Sarkis, J., Talluri, S. (2004). Performance-Based Clustering for Benchmarking of US Airports. Transportation Research Part A, 38, 329346.

Silva, E., Mendes, A.B. and Santos, J. (2012a). Efficiency Measures in the Agricultural Sector: The Beginning in Efficiency Measures in the Agricultural Sector with applications, 3-17. Springer Editor.

Silva, E., Arzubi, A. and Berbel, J. (2012b). An Application of Data Envelopment Analysis (DEA): in Azores Dairy Farm sin Efficiency Measures in the Agricultural Sector with applications, 73-83. Springer Editor.

Silva, E., Santos, C. and Mendes, A. (2012c). Animal Grazing System Efficiency: in Efficiency Measures in the Agricultural Sector with applications, 83-93. Springer Editor.

Simar, L., Wilson, P. (2008). Estimation and Inference in Two-Stage, Semi-Parametric Models of Production Processes. Journal of Econometrics, 1, 342-365.

Surugiu, C., Leitão, N.C. and Surugiu, M.R. (2011). A Panel Data Modelling of International Tourism Demand: Evidences for Romania. Economic Research, 24 (1), 134-145.

Speelman, S., D'Haeseb, M, J Buyssea J. and D'Haesea L. (2007). Technical efficiency of water use and its determinants, study at small Scale irrigation schemes in North-West Province, South Africa Paper prepared for presentation at the 106th seminar of the EAAE.

Thiam, A., Bravo-Ureta, B.E. and Rivas, T.E. (2001). Technical efficiency in developing country agriculture: a meta-analysis. Agricultural Economics, 25, 235-243. 